\title{
Razvoj pravosudnih vlasti i odgovarajućega pravnog okvira u Hrvatskoj 1945. godine*
}

\author{
MARTINA GRAHEK RAVANČIĆ \\ Hrvatski institut za povijest \\ Zagreb, Hrvatska \\ martina@isp.hr
}

Organizacija i razvoj pravosudnih tijela i odgovarajućega pravnog okvira u Hrvatskoj nakon Drugoga svjetskog rata bila je nezaobilazna sastavnica ustrojavanja ukupne nove vlasti na ovim prostorima. Rad analizira okolnosti i uvjete u kojima se uspostavljaju sudski sustav (okružni i kotarski sudovi te „specijalni sudovi”) i tužiteljstvo u Hrvatskoj te zadaci koji su stavljani pred poslijeratno sudstvo. Naglasak je stavljen i na pitanje zakonskoga kontinuiteta, koji je osim za osiguranje legaliteta iskorišten i u svrhu izgradnje i stabilizacije nove vlasti.

Ključne riječi: pravosuđe; sudovi; zakoni; javni tužitelj; Jugoslavija; Hrvatska; 1945.

\section{Uvod}

Kaže se da istinski mir ne nastupa tek izostankom ratnih operacija, nego potpunom prisutnošću pravde. Iako su pravo i pravda dva ponekad jako udaljena pojma, jasno je da upravo pravosudni sustav, osim za uspostavu i stabilizaciju nove vlasti, služi i osiguranju pravde. U skladu s tim, u članku će se na temelju arhivskih izvora, propisa, sudske prakse, novinskih izvješća te dostupne literature analizirati razvoj pravnoga okvira izgradnje pravosudnoga sustava, posebice s obzirom na posredno priznavanje pravnoga kontinuiteta, ako nije bio u suprotnosti s načelima Narodnooslobodilačke borbe (NOB), te koliko je ta činjenica išla u korist novoj vlasti na području Hrvatske. Analizirat će se i okolnosti i uvjeti u kojima su se razvijala i djelovala onodobna pravosudna tijela, poglavito rad redovnih sudova (okružnih i kotarskih) te „specijalnih" sudova. Prikazat će se važnost i uloga tužiteljstva te zadaci postavljeni pred tu važnu instituciju vlasti. Analiza rada navedenih sudova i tužiteljstva, smatram, predstavlja najreprezentativnije sastavnice pravosudnoga sustava u nastajanju.

\footnotetext{
* Rad je nastao u sklopu projekta „Rat, žrtve, nasilje i granice slobode u hrvatskoj povijesti 20. stoljeća - WarVic" (IP-2019-04-6673), koji financira Hrvatska zaklada za znanost.
} 


\section{Razvoj pravnoga sustava prema kraju rata}

Koliko je taj zadatak bio važan, bili su svjesni i predstavnici nove vlasti na ovim prostorima. Stoga su vrlo rano započeli izdavati naputke za organizaciju pravosudnoga sustava - da bi jugoslavenska vlast osigurala svoj legalitet, ali i legitimitet. Prema povijesnoj građi Zemaljskoga antifašističkog vijeća narodnog oslobođenja Hrvatske (ZAVNOH), pri Odjelu za pravosuđe već sredinom 1943. započela je gotovo cjelovita i konzistentna pravna izgradnja. Valja napomenuti da „normativne koncepcije, pojmovni instrumenti i pravne impostacije ZAV$\mathrm{NOH}-\mathrm{a}$ polaze od fiksiranih općih principa jugoslavenskog NOB-a i revolucije". Smjernice razvoja novoga zakonodavstva najbolje opisuju riječi predsjednika Odjela pravosuđa ZAVNOH-a Ferde Čulinovića i predstojnika Odjela za upravu Leona Gerškovića: „Naše pravo mora da služi narodu, mora da osigura našu slobodu. Ono mora da zadovolji sve naše životne potrebe, a u prvom redu da onemogući svako nastojanje reakcionarnih klika, koje bi išle - ma kada i ma kako - protiv narodne slobode i svih tekovina narodno-oslobodilačke borbe."

Na zahtjev Komisije za oslobođene krajeve, Odjel pravosuđa 31. kolovoza 1944. izdao je smjernice za preuzimanje sudskih organa. Prema njima, bilo je potrebno preuzeti postojeće objekte, zatečene arhive, a državna tužiteljstva trebali su preuzeti zastupnici javnih interesa pri pojedinom narodnom sudu. Što se tiče "personalnih" pitanja, podaci su već djelomično bili prikupljeni, pa se prema njima određivao i daljnji ostanak u službi. Napominjalo se: „Ukida se sva sudbenost okupatorskih (ustaških) sudova. Sav njihov postupak i sve njihove odluke proglašuju se ništavnim.” U daljnjem radu trebalo je ustanoviti ostaju li na snazi dotadašnji zakoni ili se oni „voljom naroda” ukidaju. „Potrebno je da Predsjedništvo ZAVNOH-a donese Uredbu o ustrojstvu sudova i Uredbu o ustrojstvu državnih ili javnih tužioštava, te da imenuje Glavnog ili javnog tužioca, čija je funkcija neophodna za prve dane nakon preuzimanja vlasti." ${ }^{3}$ Dva dana poslije Odjel za pravosuđe donio je prijedloge novih normativnih akata u obliku uputstava. ${ }^{4}$ Sredinom rujna Odjel pravosuđa ZAV$\mathrm{NOH}-\mathrm{a}$ dostavio je Komisiji za novooslobođene krajeve listu spornih pitanja iz oblasti pravosuđa koja je valjalo riješiti - među njima i pitanje valjanosti zakona koji su vrijedili prije rata. ${ }^{5}$ Problem pravnoga kontinuiteta riješen je 3. veljače $1945 .{ }^{6}$ Odlukom Antifašističkoga vijeća narodnog oslobođenja Jugo-

1 KISIĆ KOLANOVIĆ, „Neki aspekti razvoja prava”, 1. Opširnije u: KISIĆ KOLANOVIĆ, „Razvoj narodne vlasti u Hrvatskoj”, passim.

2 ČULINOVIĆ, GERŠKOVIĆ, „Smjernice našeg zakonodavstva”, 179.

3 SIROTKOVIĆ, ZAVNOH. Zbornik 1944, 279-291.

4 Isto, 282-284.

Isto, 325-327.

6 SR-AJ-15-PNS FNRJ, kut. 12, 211, 212. Istoga dana AVNOJ je donio Odluku o ustanovljavanju i dužnosti javnoga tužitelja DFJ i Odluku o osnivanju Vrhovnoga suda DFJ. Zadaci javnoga tužitelja su „da vrši nadzor radi pravilnog ispunjavanja zakona od strane svih ministarstva, komisija i komiteta Savezne vlade i vlada narodnih republika i njima podčinjenih upravnih organa i ustanova, kao i od strane službenih lica i građana; da poduzima u zakonu 
slavije (AVNOJ) kojom su propisi doneseni za vrijeme okupacije proglašeni nevažećima, a propisi doneseni prije 6. travnja 1941. izgubili su pravnu snagu ako su bili u suprotnosti s tekovinama NOB-a i novim propisima. ${ }^{7}$

Na područjima koja su bila pod partizanskom vlašću začeci sudske funkcije prisutni su u tzv. narodnom suđenju, što se uglavnom provodilo protiv narodnih neprijatelja, a potom i u suđenjima u okviru narodnooslobodilačkih odbora (NOO). ${ }^{8}$ Odlukom ZAVNOH-a iz 1944. formiraju se zatim sudovi odvojeni od narodnooslobodilačkih odbora, i to kao mjesni (općinski i gradski), kotarski, okružni i Vrhovni sud ZAVNOH-a. Uz civilno sudstvo, još tijekom rata bilo je uređeno i vojno sudovanje. Pritom je posebno važna bila Uredba o vojnim sudovima VŠ NOV i POJ od 24. svibnja 1944., ${ }^{9}$ koja je bila na snazi do donošenja Zakona o uređenju i nadležnosti vojnih sudova (24. kolovoza 1945. ${ }^{10}$ i prema kojoj se umjesto vojnih sudova brigada i područja organizira višestupanjsko sudstvo kao „vojni sud korpusa, vojni sud korpusne vojne oblasti i Viši vojni sud". ${ }^{11} \mathrm{Na}$ tim su se sudovima od kazni i zaštitnih mjera izricale npr. smrtna kazna, izgon iz prebivališta, prisilni rad (u trajanju od deset mjeseci do dvije godine, „pa i više”), uklanjanje s položaja, lišavanje čina i konfiskacija imovine. ${ }^{12}$

\section{Razvoj pravnoga sustava nakon rata}

Prvih mjeseci nakon rata Uredba o vojnim sudovima bila je jedini kaznenopravni temelj za suđenja koja su u vojnim i civilnim predmetima vodili voj-

predviđene radnje kod sudova i upravnih organa radi zaštite općenarodne imovine i ispunjavanja državnih privrednih planova, kao i radi zaštite prava i na zakonu osnovanih interesa države, državnih ustanova i poduzeća, državnih organizacija i građana; da vrši gonjenje krivičnih djela”. LEGRADIĆ, BESAROVIĆ, Narodni sudovi, 35; Jakov BLAŽEVIĆ, „Javni tužioci, organi opće narodne kontrole", Vjesnik (Zagreb), 31. 5. 1945., 1.

7 SR-AJ-49-MPV FNRJ, kut. 2, oznaka 1, 2-657 do 2-660; Službeni list Demokratske Federativne Jugoslavije (Beograd), 4 (1945); SIROTKOVIĆ, ZAVNOH. Zbornik 1945, 472. Zdenko Radelić navodi da je propuštena definicija o kojim se točno tekovinama radi, posebice ako se uzmu u obzir taktiziranja koja su u to doba bila od presudne važnosti. RADELIĆ, Hrvatska u Jugoslaviji, 153.

8 KISIĆ KOLANOVIĆ, „Neki aspekti razvoja prava”, 5.

9 DŽELEBDŽIĆ, Zbornik dokumenata, 174-185; DIZDAR et al., Dokumenti, 35-42; KALOĐERA, Vojni pravosudni organi, 13-17; ŠNUDERL, Materialno kazensko pravo, 6-9; JURČEVIĆ, IVANDA, „Ustrojavanje sustava jugoslavenskih komunističkih vojnih sudova”, 912 (bilj. 60).

10 Službeni list Demokratske Federativne Jugoslavije, 65 (1945); KALOĐERA, Vojni pravosudni organi, 21-26; GOJKOVIĆ, Historija jugoslovenskog vojnog pravosuđa, 132.

11 GOJKOVIĆ, Historija jugoslovenskog vojnog pravosuđa, 127-129; GERŠKOVIĆ, Dokumenti o razvoju narodne vlasti, 1. Vojni sud korpusa i korpusne vojne oblasti sudio je isključivo u prvom stupnju, a Viši vojni sud sudio je u prvom i u drugom stupnju. No o suđenju u drugom stupnju može se govoriti uvjetno s obzirom na to da Uredba o vojnim sudovima nije predviđala pravo žalbe. KALOĐERA, Vojni pravosudni organi, 24.

12 GOJKOVIĆ, Historija jugoslovenskog vojnog pravosuđa, 129; KALOĐERA, Vojni pravosudni organi, 15; RADELIĆ, Hrvatska u Jugoslaviji, 61. 
ni sudovi. U travnju 1945. Uredba je dopunjena odredbom o kaznama zatvora i povjerljivim uputama Ministarstva obrane. Prijelaz na redovno sudstvo označilo je prihvaćanje Zakona o krivičnim djelima protiv naroda $i$ države od 25. kolovoza 1945. (izmijenjen i dopunjen u srpnju 1946.). ${ }^{13}$ On je ujedno bio jedan od temelja sistemskoga normiranja kaznenopravne materije do donošenja Općega dijela Krivičnog zakonika FNRJ 1947. godine. ${ }^{14}$ Kaznenim djelom protiv naroda i države smatrala se „svaka radnja kojom se ide za tim da se putem nasilja obori ili ugrozi postojeće državno uređenje Federativne Narodne Republike Jugoslavije, ili da se ugrozi njena vanjska sigurnost ili temeljne demokratske, političke, nacionalne i ekonomske tekovine oslobodilačkog rata: federativno uređenje države, ravnopravnost i bratstvo i jedinstvo jugoslavenskih naroda i narodna vlast”. Određeno je da za „krivična djela iz ovog Zakona sude u prvom stepenu narodni okružni sudovi, a za vojna lica vojni sudovi”, no u „naročito važnim slučajevima sudit će [...] zemaljski vrhovni sudovi, a ako je takvo djelo od općeg državnog značaja vojno vijeće saveznog Vrhovnog suda odnosno Vrhovni sud". ${ }^{15}$

Zakon o krivičnim djelima protiv naroda $i$ države temeljen je na sovjetskom kaznenom zakoniku te je kontrarevolucionarno kazneno djelo postalo glavni i opći oblik delikta protiv države. ${ }^{16}$ Slovenski javni tužitelj dr. Vito Kraigher kaže da sovjetski zakonik „[...] sadrži niz najsuvremenijih kaznenih načela koja su za našu sadašnju praksu mnogo primjerenija od načela starog jugoslavenskog kaznenog zakonika". ${ }^{17}$ Iako je prihvaćanje Zakona o krivičnim djelima protiv naroda $i$ države deklarativno označilo prelazak na redovno sudstvo, ono je ustvari dotadašnju Uredbu o vojnim sudovima tek sadržajno prilagodilo poslijeratnim prilikama, no osnova mu je i dalje odgovarala ratnom stanju, s posebnim naglaskom na mogućnost pobune protiv nove vlasti.

Zakon o konfiskaciji (9. lipnja 1945.) i uredbe kojima se regulirala zaštita narodne imovine i upravljanje njome, kao i razne upute o zapljeni, temeljili su se na Odluci o prijelazu neprijateljske imovine u državno vlasništvo (21. studenog 1944.). ${ }^{18}$ Dana 6. veljače 1945. stupila je na snagu Odluka o upravi nad

13 Službeni list Federativne Narodne Republike Jugoslavije (Beograd), 59 (1946); Zbirka krivičnih zakona sa komentarom, 9-25.

14 Službeni list Demokratske Federativne Jugoslavije, 66 (1945); Borba (Beograd), 27. 8. 1945., 4; Službeni list Federativne Narodne Republike Jugoslavije, 59 (1946); BASTAIĆ, „Razvitak organa pravosuđa”, 109; PORTMANN, „Communist retaliation and persecution”, 54.

15 Službeni list Demokratske Federativne Jugoslavije, 66 (1945); KALOĐERA, Vojni pravosudni organi, 26.

16 BAVCON, Kazneno-pravna zaštita države, 179; VODUŠEK STARIČ, „Ozadje sodnih procesov", 140; CVETKOVIĆ, Između srpa i čekića, 158. Iako se njime definiraju kontrarevolucionarna kaznena djela, taj pojam pojavljuje se u naslovu zakonika tek 1951. jer u onodobnim okolnostima nije bilo poželjno izjednačavati NOB i socijalističku revoluciju.

17 VODUŠEK STARIČ, Prevzem oblasti, 18; VODUŠEK STARIČ, Kako su komunisti osvojili vlast, 25.

18 GEIGER et al., Dokumenti: Zagreb i središnja Hrvatska, 497 (preuzeto iz: FERENC, Kočevska pusta in prazna, 304); ANIĆ, „Normativni okviri podržavljenja imovine”, 34. 
imovinom neprisutnih lica i o sekvestru ${ }^{19}$ nad imovinom koju su okupatorske vlasti prisilno otuđile. ${ }^{20}$ Odlukom je u državno vlasništvo prešla sva imovina Trećega Reicha i njegovih državljana s područja Jugoslavije, sva imovina osoba njemačke narodnosti osim onih koji su se borili u redovima NOB-a ili su podanici neutralnih država, sva imovina ratnih zločinaca i njihovih pomagača, kao i imovina osoba koje su presudom građanskih ili vojnih sudova bile osuđene na gubitak imovine. Imovinom su se, u skladu s tim propisima, smatrala nepokretna dobra, pokretna dobra i prava, zemljišni posjedi, kuće, namještaj, šume, rudarska prava, poduzeća sa svim društvima, udruženja, fondovi, platežna sredstva, autorska prava, prava industrijske svojine i dr. Prema tome, bio je pokriven gotovo svaki oblik imovine.

Zakonom o konfiskaciji namjeravalo se otkloniti sve eventualne nejasnoće uočene pri provođenju konfiskacije prema prije važećim propisima. Prema definiciji objavljenoj u Vjesniku (15. svibnja 1945.), konfiskacija je opisana kao „vojno sudski akt, ona je kazna koju imadu da podnesu svi narodni neprijatelji” ${ }^{21}$ Primjenjivala se na sva imovinska prava, a vlast koja je pokretala postupak bila je zadužena za prikupljanje svih potrebnih podataka o imovini osobe protiv koje se pokretao postupak. Postupak su pokretali narodnooslobodilački odbori i na temelju njihovih izvještaja vojni sudovi izricali su presude o zapljeni imovine. Konfiscirana imovina ulazila je u Narodnooslobodilački fond i njome je upravljao NOO, s time da su vojne vlasti imovinom iz Fonda raspolagale prema vlastitim potrebama. ${ }^{22}$ Pri provođenju konfiskacije, osim dokazivanja krivnje, ključni element bili su politički i gospodarski ciljevi Komunističke partije Jugoslavije. Na njezinu 5. kongresu, održanom 1948., Dušan Brkić konstatirao je da je cjelokupni gospodarski sektor iznikao iz konfiscirane imovine, točnije „te konfiskacije imale su i imaju, bez sumnje, svoj revolucionarni značaj i klasnu pozadinu”. ${ }^{23}$ Često se naglašavalo da se konfiskacijom imovine suradnika okupatora onemogućavala ekonomska podloga fašizma, čime je ujedno kaznena mjera konfiskacije dobivala širi kontekst. ${ }^{24}$

19 Stavljanje imovine pod sekvestar bilo je privremena i preventivna mjera oduzimanja imovine vlasnika od strane izvršnih tijela vlasti sve do donošenja sudske odluke. Sekvestrirala se ona imovina za koju nije donesena odluka o konfiskaciji zbog toga što postupak nije pokrenut ili je u tijeku. Vidi: Službeni list Demokratske Federativne Jugoslavije, 40 (1945).

20 Službeni list Demokratske Federativne Jugoslavije, 2 (1945); ANIĆ, „Normativni okviri podržavljenja imovine", 34; SIROTKOVIĆ, ZAVNOH. Zbornik 1945, 481-493; NEŠOVIĆ, Zakonodavni rad Pretsedništva Antifašističkog veća, 225-240.

${ }^{21}$ NOVAK, STOPAR, Vjesnik jedinstvene narodno-oslobodilačke fronte, 421; MIKOLA, Zaplembe premoženja, passim; MIKOLA, „Povojne nasilne razlastitve”, 53-64.

${ }_{22}$ Do kraja 1945. na osnovi konfiskacije u državno vlasništvo prešlo je $55 \%$ od ukupnih industrijskih kapaciteta u Jugoslaviji, a 27 \% bilo je sekvestrirano. Tako je podržavljeno $82 \%$ ukupne industrije. U Srbiji je do sredine prosinca pokrenut 11381 predmet, od čega je čak 60 $\%$ dobilo konačnu odluku (u Beogradu $80 \%$ ). Realizirano je oko 4880 konfiskacija, a najčešće se konfiskacija odnosila na zgrade, poljoprivredne posjede, šume i zanatsko-trgovačka poduzeća. MITROVIĆ, Srbija 1944 - 1952, 202-210.

23 RADELIĆ, Hrvatska u Jugoslaviji, 183.

24 MILIĆEVIĆ, Jugoslovenska vlast i srpsko građanstvo, 140. 
Oduzimanjem imovine nastojalo se stvoriti besklasno društvo s gospodarski ovisnim pojedincima. ${ }^{25}$ Koliko je bilo važno normirati privrednu suradnju, potvrđuje činjenica da je to učinjeno u čak tri navrata (u Odluci o zaštiti nacionalne časti Hrvata i Srba u Hrvatskoj od 24. travnja 1945., Zakonu o biračkim spiskovima od 11. kolovoza 1945. i Zakonu o krivičnim djelima protiv naroda $i$ države od 25. kolovoza 1945.).

Na prijedlog Andrije Hebranga 23. travnja 1945. prihvaćen je i Zakon o suzbijanju nedopuštene špekulacije i privredne sabotaže, koji je vrlo široko tumačio pojam špekulacije. Široko tumačenje pojma vidljivo je i u Zakonu o oduzimanju ratne dobiti stečene za vrijeme neprijateljske okupacije, prema kojem je kao višak određeno sve ono što je bilo stečeno u odnosu na stanje do 6 . travnja 1941. godine. Posebne peteročlane komisije na temelju osobne procjene utvrđivale su visinu dobiti, pa je tako određeno da sva dobit iznad 25.000 dinara (koliko se moglo zaraditi u normalnim uvjetima) mora biti oduzeta. Prikupljena imovina išla je u Fond za obnovu zemlje i pomoć stradalim krajevima, čime se poticala obnova. ${ }^{26}$ Prema zakonu, „ratni dobitnici” morali su se sami prijavljivati, što naravno nije bilo popraćeno velikim odazivom, pa se djelotvornijom pokazala denuncijacija. Ipak, provedba te odredbe bila je vrlo detaljna jer je, kako se navodi, dovela „do nesigurnosti građana” ${ }^{27}$ Primjerice, u Beogradu je u pola godine (do travnja 1946.) broj prijavljenih osoba skočio na $6000 .^{28}$ Bilo je i prigovora o preblagom kažnjavanju jer, kako se napominjalo, nije u pitanju „opseg same cijene”, nego kakve posljedice izaziva takva pojava. Stoga je zaključeno da „[...] bi ovakove krivce trebalo kažnjavati prisilnim radom dužega trajanja sa svima posljedicama skopčanima sa takovom kaznom [...] Odlučna, energična, pravilna, a u slučajevima potrebe i drastična primjena zakona jest garancija brze obnove zemlje, što je sada nakon dobivenoga rata najsvetiji zadatak svakog gradjanina ove zemlje". ${ }^{29}$

Koliko je bilo važno shvatiti značaj pravilnoga tumačenja i provođenja novih zakona jasno su oslikavali i novinski članci objavljeni u onodobnom tisku. Primjerice, na konferenciji narodnih tužitelja za kotar Sušak u Bakru rečeno je da zakoni idu „za učvršćenjem i proširenjem u borbi postignutih tekovina, a protiv svega što se kosi sa narodnim interesima”. U tekstu se pozivalo na diskontinuitet pravnih propisa te jasno isticalo: „[...] kroz NOB stvoreno je novo narodno zakonodavstvo. Stvoreni su novi narodni zakoni, koji se iz korijena razlikuju od onoga što se zvalo zakonom u bivšoj Jugoslaviji. Novi narodni zakoni vuku svoju osnovu iz tekovina NOP-a, oni su izraz volje i želja naroda, oni su široko demokratski, jer izražavaju volju ogromne većine naroda. Oni su upereni protiv svih protunarodnih elemenata, koji su u toku borbe pokušavali

25 RADELIĆ, Hrvatska u Jugoslaviji, 178, 179.

26 Službeni list Demokratske Federativne Jugoslavije, 36 (1945).

27 RADELIĆ, Hrvatska u Jugoslaviji, 182; MILIĆEVIĆ, Jugoslovenska vlast i srpsko gradanstvo, 161-162.

28 MILIĆEVIĆ, Jugoslovenska vlast i srpsko građanstvo, 165.

29 HR-DAZG-1216-ONS GZ, kut. 9, Su: 212/1945, 9. 8. 1945. 
ili će još i u buduće pokušavati, da stanu na put našim narodima u borbi za bolju i sretniju budućnost." ${ }^{30}$ Upozorenja da sudovi nisu dovoljno upoznati s novim propisima stalno su se ponavljala, no napominjalo se da su oni „donijeti u duhu tekovina Narodno-oslobodilačke borbe" - s čime svi moraju biti upoznati te se na tome treba najozbiljnije raditi. ${ }^{31}$

\section{Organizacija, rad i zadaci redovnih narodnih sudova}

Tijekom lipnja 1945. pored vojnih sudova s radom su počeli i redovni narodni sudovi. Prema teritorijalnoj nadležnosti, redovni narodni sudovi bili su podijeljeni na kotarske, okružne, vrhovne sudove pojedinih federalnih jedinica te Vrhovni sud Demokratske Federativne Jugoslavije (DFJ). ${ }^{32}$ Sredinom srpnja, na savjetovanju narodnih sudaca, ministar pravosuđa rekao je da je u tom trenutku na području Hrvatske bilo organizirano 19 okružnih sudova i 116 kotarskih narodnih sudova te je osim toga postojao Vrhovni sud Hrvatske $\mathrm{u}$ Zagrebu. ${ }^{33} \mathrm{Na}$ drugom savjetovanju, u prosincu iste godine, izneseno je da je tada na području Hrvatske bilo organizirano 17 okružnih i 109 kotarskih sudova. ${ }^{34}$

Kao osnovni zadatak sudova istaknuta je zaštita „demokratskih tekovina NOB-a”. Na drugome mjestu bila je zaštita prava i interesa ustanova, poduzeća i organizacija te na kraju i zaštita prava pojedinaca. Iz navedenoga redoslijeda jasno se očituje misija poslijeratnoga sudstva. ${ }^{35}$ Primarna je bila afirmacija novoga političkog sistema, a tek nakon toga zaštita individualnih prava i sloboda. Tako posloženi zadaci sudova najbolje se očituju u analizi kaznenoga aspekta pravnoga sustava. Koliko su ti zadaci važni, potvrđuje i činjenica da je već 12. svibnja 1945. na sastanku Mjesnoga komiteta Komunističke partije Hrvatske u Zagrebu među ostalim rečeno: „Potrebno je uspostaviti sudove Komande Grada." 36

30 „Duh zakonodavstva nove Jugoslavije”, Primorski vjesnik (Rijeka), 10. 8. 1945., 2.

31 HR-DAZG-1216-ONS GZ, kut. 9, Su: 234/1945, 14. 8. 1945.

32 Spomenuti sudski ustroj uređen je Zakonom o uredenju narodnih sudova od 26. kolovoza 1945. Vidi: Službeni list Demokratske Federativne Jugoslavije, 67 (1945).

33 „Naše sudstvo. Izjava ministra pravosuđa Federalne Hrvatske Dušana Brkića”, Vjesnik, 16. 7. 1945., 1.

34 „Naš narod hoće i traži pravedno i oštro kažnjavanje svih neprijatelja naše zemlje i brzo sudovanje naših sudova", Vjesnik, 12. 12. 1945., 3. Prema podacima Predsjedništva Antifašističke skupštine narodnog oslobođenja Srbije (ASNOS) od 2. travnja 1945., na području Srbije (izuzev Beograda) organizirano je 16 okružnih i 97 kotarskih sudova. Na području Beograda bila su organizirana 2 okružna i 6 kotarskih sudova. Prvi okružni sud i drugi sreski sud za Beograd otpočeli su s radom 30. ožujka 1945. godine. SR-AJ-49-MPV FNRJ, kut. 54, oznaka 97, 61. Prema dopisu od 28. kolovoza 1945. započelo je s radom 6 okružnih te 13 kotarskih sudova u Crnoj Gori. HR-DAZG-1216-ONS GZ, kut. 9, Su: 253/1945, 23. 8. 1945. Krajem kolovoza 1945. u Makedoniji su organizirana 3 okružna i 26 kotarskih sudova. HR-DAZG-1216-ONS GZ, kut. 9, Su: 265/1945, 31. 8. 1945.

${ }_{35}$ KISIĆ KOLANOVIĆ, „Pravno utemeljenje državnocentralističkog sistema”, 62.

36 GEIGER et al., Dokumenti: Zagreb i središnja Hrvatska, 340. 
Okružni narodni sud za grad Zagreb (kao sud prvoga i drugoga stupnja), kao i Okružni narodni sud za okrug Zagreb, započeo je s radom 9. lipnja 1945. na adresi Amruševa ulica 2 u Zagrebu (prvi kat). ${ }^{37}$ Okružni narodni sud za okrug Zagreb bio je nadležan za sljedeće kotarske sudove: Donja Stubica, Dugo Selo, Jastrebarsko, Klanjec, Samobor, Sveti Ivan Zelina, Velika Gorica i Kotarski narodni sud za kotar Zagreb. Dan prije (8. lipnja) s radom su započeli i Kotarski narodni sud za grad Zagreb za područje Gradskoga narodnog odbora Zagreb (podijeljeno u sedam rajona) i Kotarski narodni sud za vanjski kotar odnosno kotar Zagreb. ${ }^{38} \mathrm{Za}$ analizu su izabrani sudovi za grad Zagreb i zagrebački okrug jer su najveći i za njih postoje najpotpuniji podaci o organizaciji i osoblju te njihovoj stručnoj spremi, pa smatram da kao takvi mogu poslužiti kao dobar ogledni primjer.

Zakonom o uređenju narodnih sudova (26. kolovoza 1945.) utemeljena je organizacija i nadležnost kotarskih i okružnih sudova, koja se neznatno dopunjavala i mijenjala (1946. i 1948.). ${ }^{39}$ Stvarna nadležnost tih sudova protezala se na građanske i kaznene predmete, pri čemu se u kaznenim predmetima sudilo u vijeću. Okružni sudovi obavljali su nadzor nad kotarskim sudovima i odlučivali o žalbama protiv presuda kotarskih sudova. Ujedno su u prvom stupnju bili nadležni za kaznena djela protiv naroda i države, protiv službene dužnosti, protiv opće sigurnosti ljudi, imovine i javnoga prijevoza, za djela pravljenja i uporabe lažnih isprava, lažnoga novca, oporuka, čekova i vrijednosnih papira, kaznena djela protiv općenarodne imovine, špekulacije i sabotaže. U građanskim predmetima njihova je nadležnost, među ostalim, obuhvaćala imovinsko-pravne sporove u kojima je jedna stranka bila država, državno poduzeće ili ustanova.

Oba okružna suda bila su organizirana po istom principu te je pisarnica obavljala uredske poslove, svaki zaprimljeni podnesak upisivao se u odgovarajući upisnik i imenik, a radom suda rukovodio je predsjednik suda, koji je ujedno sazivao sjednice, analizirao izvješća o radu sudskih vijeća te ih upućivao višoj instanci.

Navedeni okružni sudovi sa sjedištem u Zagrebu prestali su s radom 30. lipnja 1949., kada je ustrojen jedan Okružni sud u Zagrebu sa širokom teritorijalnom nadležnošću. ${ }^{40}$ Još prije, u lipnju 1946., s radom je prestao Kotarski sud za grad Zagreb, umjesto kojega su na temelju Uredbe o ukidanju Kotarskog suda za grad Zagreb i osnivanju sudova za područje grada Zagreba osnovana tri nova kotarska suda za područje grada Zagreba. ${ }^{41}$

37 „Sastavljeni narodni sudovi u Zagrebu”, Vjesnik, 10. 6. 1945., 5.

38 Isto.

39 Službeni list Demokratske Federativne Jugoslavije, 67 (1945).

40 Narodnooslobodilački odbor Zagreb, koji je pokrivao kotareve Donja Stubica, Dugo Selo, Jastrebarsko, Samobor, Sv. Ivan Zelina, Velika Gorica i Zagreb, ukinut je 1947., no Sud je zadržao službeni naziv do samoga kraja svojega djelovanja.

41 „Uredba o ukidanju Kotarskog suda za grad Zagreb i osnivanju sudova za područje grada Zagreba”, Narodne novine (Zagreb), 107 (1946). 
Ostali redovni sudovi na području Hrvatske uglavnom su organizirani u drugoj polovini lipnja 1945. godine. Njihovo ekipiranje i rješavanje postavljenih zadataka teklo je različitim tempom. Prema podacima iz izvješća javnoga tužitelja za lipanj proizlazi da kotarski narodni sudovi u Dvoru, Kostajnici, Glini i Petrinji rade normalno, „[...] jedino što na Dvorskom kotaru nema još ni jednog pravnika, dočim kotarski narodni sud Sisak radi, ali nije pravilno biran putem Narodne skupštine. Takodjer ni u Okružni narodni sud sa kotara Sisak nisu izabrani delegati. [...] U Okružnom narodnom sudu rade dva pravnika" ${ }^{42}$

Sredinom srpnja organizacijski problemi su ponešto drugačiji, ali i dalje izrazito prisutni. Iz izvješća o radu javnih tužitelja za karlovački i banijski okrug proizlazi da u to vrijeme još nije bilo dovoljne koordinacije rada među svim dijelovima narodne vlasti. „Krivična odjeljenja razvila su rad; običnog kriminala je malo [...] Nekih naročitih problema nema, jer su sudovi sređeni. Rad sudova nacionalne časti bio je do mog dolaska slab." ${ }^{33}$ Izvješće za Karlovac za lipanj i srpanj 1945. navodi da je ukupno podignuto 13 optužnica - od toga 8 na Okružnom sudu, a 5 pred Sudom za zaštitu nacionalne časti Hrvata i Srba u Hrvatskoj. U postupku su bila ukupno 34 predmeta. ${ }^{44}$ Javni tužitelj tih okruga bio je vrlo aktivan u organiziranju konferencija na kojima se zaposlenike sudova upoznavalo s pravnim propisima, njihovim tumačenjem i primjenom. To je svakako pridonosilo i boljim rezultatima rada nadležnih sudova.

I okrug Bjelovar borio se sa sličnim problemima. Krajem srpnja javno tužiteljstvo još uvijek nije bilo potpuno organizirano i iz toga su proizlazili brojni problemi, no „ipak smo uspjeli da kaznimo odnosno da privedemo kazni one najglavnije, koji su se stavili u službu okupatora i njihovih pomagača, bilo to po vojnom sudu bilo to po sudu za zaštitu nacionalne časti" . ${ }^{45} \mathrm{I}$ u tim slučajevima naglasak je bio na privrednoj suradnji s neprijateljem, što je za novu vlast bio veliki problem s kojim se valjalo obračunati, ali ujedno i izvor za povećanje državne imovine.

Gotovo istovremeno Okružni sud za Istru sa sjedištem u Labinu izvještava javnoga tužitelja o neodgovarajućim prostorijama u kojima rade te nedovoljnom broju osoblja, a pred njima se otvara sve više zadataka. ${ }^{46}$ Tek iz izvješća za listopad vidljiv je izvjesni napredak u ekipiranju osoblja. Određeno rasterećenje donijelo je i to što je tih dana napokon organiziran Okružni sud za Rijeku - s obzirom na to da se radilo o gradu s autonomnom upravom. ${ }^{47} \mathrm{Iz}$ navedenog jasno proizlazi da je organiziranje sudova išlo različitim tempom,

42 HR-HDA-421-JT SRH, kut. 5, br. 39/45, 30. 6. 1945.

43 GEIGER et al., Dokumenti: Zagreb i središnja Hrvatska, 515-516.

44 Isto, 544-545.

45 DIZDAR et al., Dokumenti, 229-231; GEIGER et al., Dokumenti: Zagreb i središnja Hrvatska, 553-555.

46 HR-HDA-421-JT SRH, kut. 5, br. 44/45, 8. 7. 1945.

47 HR-HDA-421-JT SRH, kut. 5, br. 44/45, 7. 10. 1945. 
pa ni njihovi rezultati rada nisu mogli biti jednaki. Tako Okružni sud za Rijeku u listopadu 1945. kaže da se i dalje bore s brojnim nedostacima. Posebno ističu problem primjenjivosti određenih zakona na području Vojne uprave te izoliranost u pogledu dobivanja informacija, poglavito uslijed otežane prometne povezanosti, ali i neredovite dostave poštanske službe.

Još jedno upozorenje o nedovoljnoj koordinaciji rada među različitim dijelovima narodne vlasti došlo je u kolovozu iste godine iz Ministarstva pravosuđa Narodne Republike Hrvatske. U njemu se protestiralo zato što su službenici okružnih i kotarskih sudova zapošljavani, premještani i otpuštani bez znanja i odobrenja nadležnoga ministarstva. U zaključku je stajalo da je takva praksa možda i bila opravdana kada je nedostajalo ljudstva, no sada su sudovi popunjeni potrebnim osobljem, pa se s tom praksom mora prekinuti. ${ }^{48} \mathrm{Ni}$ krajem 1945. nisu prestajali prigovori, pa je Ministarstvo pravosuđa poslalo okružnim narodnim sudovima požurnicu u kojoj se tražilo da se što brže završavaju istrage u pitanju istražnoga zatvora te da se u što kraćem vremenu sastave optužnice u tim predmetima i predaju nadležnim sudovima na daljnje postupanje. $^{49}$

Možda najbolji sumarni pregled s kraja godine ponuđen je na drugom savjetovanju narodnih sudaca. Prema njemu, zabilježen je znatan napredak u razvoju sudstva na općenitoj razini. U prvom redu to se odnosilo na formiranje i popunjavanje zadovoljavajućim kadrom - jednoga dijela sudova, no jasno je upozoreno i na brojna kašnjenja pri organiziranju pojedinih sudova. Kašnjenja su povezivana s obimom ratnih operacija na pojedinim područjima i kontinuitetom rada, tj. s time jesu li pojedini sudovi bili organizirani od početka ili su imali neke temelje još iz vremena rata. ${ }^{50}$ Okupljeni su bili svjesni da je, osim toga, još mnogo zadataka ostalo neriješeno.

Što se tiče osoblja koje je radilo pri sudovima, navest ću za primjer Okružni narodni sud za grad Zagreb, gdje je za predsjednika imenovan Ivan Poldrugač (bivši vijećnik Banskoga stola) iz Zagreba, za potpredsjednika dr. Adalbert Miljan (bivši vijećnik Sudbenoga stola u Zagrebu), a uz njih su imenovana i 24 člana prisjednika. Za predsjednika Kotarskoga narodnog suda za grad Zagreb imenovan je dr. Antun Pecikozić (bivši vijećnik Sudbenoga stola u Zagrebu) te 18 članova prisjednika. Među članovima prisjednicima suda bili su ljudi različitoga obrazovanja i zanimanja, no veći dio bio je niže kvalificiran. ${ }^{51}$ Isti princip očit je i u sastavima ostalih sudova na području Hrvatske. I u pitanju općih kvalifikacija sudaca najvažniji element bila je vezanost za principe NOB-a. Pritom se nije smatralo da je njegova uloga tek birokratsko provođenje odluka Partije, nego je on pozvan da „kao aktivni činilac konkretizira opće formule

48 HR-DAZG-1216-ONS GZ, kut. 9, Su: 228/1945, 14. 8. 1945.

49 GEIGER et al., Dokumenti: Zagreb i središnja Hrvatska, 783-784.

50 „Naš narod hoće i traži pravedno i oštro kažnjavanje svih neprijatelja naše zemlje i brzo sudovanje naših sudova", Vjesnik, 12. 12. 1945., 3.

51 „Sastavljeni narodni sudovi u Zagrebu”, Vjesnik, 10. 6. 1945., 5. 
i standarde, i pravni odnos razriješi u korist općeg interesa NOB-a". ${ }^{52}$ Za narodnoga suca mogao je biti izabran svaki punoljetan i neporočan građanin. No, ako se detaljnije sagleda to opće načelo, jasno proizlazi da je ipak najveću važnost imala politička orijentacija samoga suca. ${ }^{53}$ Konkretnije: „[...] u personalnim pitanjima treba se upustiti u pitanje ocjene političkog autoriteta i uticaja na narod, te poznavanja problema organizacije Narodno-Oslobodilačkog pokreta." ${ }^{54}$ Pritužbe na kadar nisu rijetke. Primjerice, za područje Istre navodi se: „Oni se tamo slabo ponašaju i nosioci su jedne politike, koja je nama strana. Oni bremzaju naše sudove u sudjenju prikazujući to, kao nešto za sada još nepotrebno." 55

Povećanje broja pravnih normi, kao i njihova sve složenija primjena, zahtijevalo je sveobuhvatno školovanje pravnoga kadra te uključivanje nekompromitiranih pojedinaca školovanih u starom sustavu. ${ }^{56} \mathrm{Da}$ opće stanje nije bilo bajno i da se nailazilo na brojne poteškoće pri organiziranju sudstva, bilo je jasno i ministru pravosuđa, koji je na savjetovanju narodnih sudaca sredinom srpnja 1945. istaknuo značenje suca i važnost zadatka postavljenog pred njega - kao nastavak četverogodišnje borbe u ratu. ${ }^{57}$ Zanimljiva zapažanja iznosi Petar Meandžija kada govori o iskustvu u radu Kotarskoga narodnog suda u Glini te objašnjava kako je narod prihvatio nove suce. „Prvo što je zapazio, da namjesto školovanog suca sjede seljaci. Ova je promjena prošla vrlo povoljno, jer su je ustankom oslobođeni krajevi sami stvorili. Iskustvo je pokazalo, da i novooslobođena područja dobro prihvaćaju ovu korisnu novotu. [...] Iskustvo je pokazalo, da sudstvo nije izgubilo ugled promjenom u osobi suca. Narod samo postavlja i na njih zahtjev pravednosti i održavanja potrebnih formalnosti." ${ }^{58}$ Unatoč tome, javni tužitelj Hrvatske u svojem izvješću iz srpnja 1945. upućenom javnom tužitelju DFJ navodi da postoje reakcije u narodu jer „slabost ličnog sastava suda uzrok je nepravednih presuda u bilo kom pravcu". ${ }^{59} \mathrm{Na}$ drugom savjetovanju narodnih sudaca, u prosincu iste godine, zabilježen je znatan napredak u razvoju sudstva: „Mi smo u ovom periodu vidjeli, koji je od sudaca istinski narodni čovjek, koliko i kako čuva tekovine narodno oslobodilačke borbe." ${ }^{60}$ Osvrt na utemeljenost presuda tom je prilikom - izostao.

52 KISIĆ KOLANOVIĆ, „Neki aspekti razvoja prava”, 7.

53 SIROTKOVIĆ, ZAVNOH. Zbornik 1944, 445-446.

54 HR-HDA-421-JT SRH, kut. 5, br. 1/45, 4. 6. 1945.

55 Isto.

56 KISIĆ KOLANOVIĆ, „Neki aspekti razvoja prava”, 8; „Pravnici se upoznaju s organizacijom novog sudstva. Konferencija pravnika o aktuelnim političkim i stručnim pitanjima", Vjesnik, 29. 5. 1945., 3; „Naše sudstvo. Izjava ministra pravosuđa Federalne Hrvatske Dušana Brkića", Vjesnik, 16. 7. 1945., 1.

57 „Izabrani suci, radeći u interesu naroda, podići će ugled narodnih sudova”, Vjesnik, 14. 7. 1945., 3 .

58 MEANDŽIJA, „Iskustva iz našeg narodnog sudstva”, 112.

59 HR-HDA-421-JT SRH, kut. 5, br. 44/45, 14. 7. 1945.

60 „Naš narod hoće i traži pravedno i oštro kažnjavanje svih neprijatelja naše zemlje i brzo sudovanje naših sudova”, Vjesnik, 12. 12. 1945., 3. 
Kada se govori o presudama sudova, zanimljivo je izvješće Odjeljenja zaštite naroda (OZNA) za okrug Banija s početka lipnja 1945. u kojem se analizira rad Oblasnoga suda. ${ }^{61}$ Glavne kritike odnose se nanovo na utemeljenost nekih presuda. Načelnik kaže da, po njegovu mišljenju, „nešto nije u redu u Oblasnom sudu, pošto se tamo nalazi Branko Novaković, koji je mislim nešto bio zapleten blizu četničke afere na Kordunu te je poslije poslan na Baniju, a sada je ponovno povučen na višu dužnost u Vojnu oblast IV. korpusa, navedeni češće puta dolazi u Vojni sud našeg Područja, gdje im daje sugestije, kako treba suditi”. Navedeni je u jednom slučaju, u kojem je OZNA predložila smrtnu kaznu, urgirao i tražio da se kazna preinači u 5 godina robije. No „nije ovo samo jedan zapisnik, desetak zapisnika imade kod mene, koji se po mome mišljenju nepravilno izrečene osude. Još se je jedno moglo zapaziti kod suda da ona lica, za koje mi pravimo smrtnu kaznu neće da donesu, dok za ona za koja zatražimo par godina robije, osude na smrt [...] mi nemamo ništa protiv toga ako oni nekoga još oštrije osude, ali ne možemo se s time složiti da [za] ovakve teške optužbe kao što vidite iz zapisnika dobije samo tri godine". ${ }^{62}$ Osim toga u okrugu Banija uočeno je da se ljudi podosta žale na presude općinskih sudova, pa se napominje da bi valjalo ukinuti te sudove, kako je to bilo predviđeno i već učinjeno u pojedinim područjima. ${ }^{63}$ Problem neutemeljenosti presuda očito nije bio nepoznanica za nadležne, no njegovo rješavanje nije išlo zadovoljavajućom brzinom.

Smatram važnim izdvojiti da je Vrhovni sud Hrvatske 11. kolovoza poslao Predsjedništvu Okružnoga narodnog suda za grad Zagreb dopis u kojem je upozorio na nedostatke koji su se pojavljivali i „ponavljali”. Vrlo konkretno spominje se da su se sudski zapisnici toga suda sastavljali „bez dovoljne pomnje”, pa se „u njima nailazi na rečenice koje se samo teško dadu razumjeti, a više puta se u opće ne mogu razumjeti [...]”. Isti problem uočen je i u presudama i rješenjima. Vrhovni sud napominjao je: „[...] u razlozima presuda često se pojavljuju izvjesne tvrdnje, koje se odnose na neke navodne izjave stranaka za vrijeme rasprave, o kojim izjavama u raspravnim zapisnicima nema baš nikakva traga.” Upravo zbog toga „nastaju protuslovlja izmedju presude i sadržaja spisa”. ${ }^{64}$ Ovo posljednje bilo je ozbiljan problem ako govorimo o radu sudova - pogotovo stoga što se ne radi o razdoblju početnoga organiziranja i uočavanja eventualnih nedostataka i problema.

Na drugom savjetovanju narodnih sudaca, u prosincu 1945., unatoč određenom napretku u razvoju sudstva, upozorava se i na nedostatke, u prvom

${ }_{61} \mathrm{Na}$ temelju trećih uputa Odjela za pravosuđe ZAVNOH-a o preuređenju sudova od 15. studenog 1944., sudski sustav čine: općinski, kotarski, okružni, oblasni i Sud ZAVNOH-a kao Vrhovni sud.

62 GEIGER et al., Dokumenti: Zagreb i središnja Hrvatska, 423-424.

${ }^{63}$ Isto, 515-516. Ovi navodi svjedoče da je organizacija sudova još uvijek temeljena na uputi Odjela za pravosuđe ZAVNOH-a o preuređenju sudova od 15. studenog 1944., prema kojoj sudski sustav čine općinski, kotarski, okružni, oblasni i Sud ZAVNOH-a kao Vrhovni sud.

${ }^{64}$ HR-DAZG-1216-ONS GZ, kut. 9, Su: 224/1945, 11. 8. 1945. 
redu na nedosljedno primjenjivanje zakona. ${ }^{65}$ Problemu se nastojalo doskočiti učestalim organiziranjem konferencija na kojima se upućivalo u temeljna načela poslijeratnoga zakonodavstva. ${ }^{66} \mathrm{O}$ sličnom svjedoči i izvješće javnoga tužitelja za okrug Varaždin s kraja kolovoza: „[...] održavaju se konferencije na kojima će se proučavati pojedini zakoni, te kako bi oni iste mogli tumačiti narodu, a i kako bi pazili na točno njihovo izvršavanje. [...] Još nije bilo slučaja, da bi narodni tužioc učio neki zakon sa narodom u svojem selu, te da bi ga narodu tumačio. Jasno je, da je to manjkavost, koju treba, a koju ćemo i otkloniti." Napominje se da se u varaždinskom uredu radi kolektivno i da se zakoni zajednički proučavaju, što naravno rezultira jednoobraznom primjenom zakona i propisa. ${ }^{67}$ Organiziranje konferencija zasigurno je imalo učinka na pravilnije tumačenje zakona, no problemi su i dalje postojali. Rečeno je da je na konferencijama odlučeno da „se zajednički prikupi materijal i povede postupak na prvom mjestu protiv onih lica koja su privredno surađivali s okupatorom, kao i onih koji danas prikriveno rovare protiv narodne vlasti, te da im se čim prije sudi" ${ }^{68}$ Privredna suradnja s okupatorom podrazumijevala je i važno pitanje konfiskacije (podsjećam da je to pitanje čak tri puta zakonski normirano).

Stoga se često isticalo: „Naročitu pažnju treba posvetiti neriješenim predmetima konfiskacije. Kod rješavanja tih problema treba postupati najsavjesnije i najhitrije, jer se radi o imovini narodnih neprijatelja koja mora biti sačuvana za državnu zajednicu." ${ }^{69} \mathrm{U}$ tom smislu vrlo jasno govori i dokument koji je u travnju 1945. otposlan svim okružnim upravama narodnih dobara i svim okružnim narodnooslobodilačkim odborima: „Opazilo se medjutim da i nakon izdavanja gornjih Uputstava, a i nakon propusta koji su se ovdje ondje dogadjali ranije pri rukovanju pomenutom imovinom, na područjima nekih Okružnih NOO-a i dalje se ne vodi računa, da se državna imovina te ona kojom država privremeno upravlja, čuva i sačuva, odnosno da ju se racionalno izkorišćava u cilju ekonomske i privredne obnove zemlje."70 Naravno, bilo je problema u provođenju sekvestracija i konfiskacija, pa se tako pojavljuju i pritužbe Gradske uprave narodnih dobara. Napominjalo se da su u pozivima za sud manjkavi podaci o imovini, što Predsjedništvo Okružnoga narodnog suda za grad Zagreb potvrđuje; dapače, u dopisu iz rujna traži se da se „[...] obrazloži cijeli postupak počam od stavljanja prijedloga pa do okončanja stvari [...] Temeljna je pogreška, da vlasti koje su odredile konfiskaciju imovine redovno se nijesu nikako postarale da pribave podatke o imovini, koja se ima

65 „Naš narod hoće i traži pravedno i oštro kažnjavanje svih neprijatelja naše zemlje i brzo sudovanje naših sudova”, Vjesnik, 12. 12. 1945., 3.

66 DIZDAR et al., Dokumenti, 229-231; GEIGER et al., Dokumenti: Zagreb i središnja Hrvatska, 553-555.

67 GEIGER et al., Dokumenti: Zagreb i središnja Hrvatska, 631.

68 Isto, 515-516.

69 „Naš narod hoće i traži pravedno i oštro kažnjavanje svih neprijatelja naše zemlje i brzo sudovanje naših sudova”, Vjesnik, 12. 12. 1945., 3.

70 GEIGER et al., Dokumenti: Zagreb i središnja Hrvatska, 250. 
konfiscirati". ${ }^{71}$ Sud je upozorio na brojne nedostatke te zaključio da je Kotarski sud za grad Zagreb (zadužen za provođenje konfiskacija) zaprimio 2063 predmeta o konfiskaciji, od kojih je do tada dovršeno tek 217. Prema mišljenju suda, rješenje problema bilo je u povećanju broja službenika zaduženih za to pitanje jer postojećim stanjem nikako nisu bili zadovoljni.

Ista instanca mjesec dana poslije nanovo upozorava na slične probleme te navodi: „[...] i sam ovaj sud muku muči stoga što presudni sudovi nisu, u najvećem dijelu presuda, dali te podatke." ${ }^{2} \mathrm{U}$ istom tonu progovara i dopis Ministarstva pravosuđa namijenjen Vojnom sudu Vojne oblasti zagrebačke Jugoslavenske armije u kojem stoji da Predsjedništvo Kotarskoga narodnog suda u Varaždinu nije zaprimilo presude nadležnoga suda u kojima je točno naznačeno što spada pod konfiskaciju. U skladu s tim, Kotarski sud nije mogao provesti „nekoliko stotina konfiskacija”, a taj je zadatak, kako napominju, bio veoma važan za državne interese. ${ }^{73}$ Kojim je intenzitetom posao poslije tekao, teško je točno utvrditi, no prema popisu predmeta pri Kotarskom sudu za grad Zagreb, konfiskacija je bila pokrenuta u 4150 predmeta. ${ }^{74}$ Svi prije izneseni podaci jasno potvrđuju koliko je pitanje konfiskacije bilo važno za novu vlast i koliku je imovinu njezinim provođenjem dobivala u državno vlasništvo.

Čini se da izvršavanje zadataka, čak i uz neke objektivne nedostatke kao što su manjak stručnoga osoblja, nepoznavanje pravnih normi i sl., nikako nije dostizalo razinu kojom bi nadležne institucije bile zadovoljne, stoga su opetovano slane nove požurnice i upozorenja.

\section{Organizacija, rad i zadaci „specijalnih” sudova}

Uz redovne narodne sudove, na temelju spominjane Odluke o zaštiti nacionalne časti Hrvata i Srba u Hrvatskoj, ${ }^{75}$ za kulturnu, gospodarsku, pravnu, propagandnu, administrativnu i sličnu suradnju s okupatorom i pomagačima sudili su sudovi za zaštitu nacionalne časti Hrvata i Srba u Hrvatskoj, koji su djelovali od 24. travnja 1945. godine. ${ }^{76}$ Ministarstvo pravosuđa Narodne vlade Hrvatske 8. svibnja ovlastilo je okružne narodne sudove da jedno svoje vijeće imenuju sudom za zaštitu nacionalne časti Hrvata i Srba u Hrvatskoj. Kazni su

71 HR-DAZG-1216-ONS GZ, kut. 9, Su: 301/1945, 20. 9. 1945.

72 HR-DAZG-1216-ONS GZ, kut. 9, Su: 360/1945, 19. 10. 1945.

73 HR-DAZG-1216-ONS GZ, kut. 9, Su: 283/1945, 24. 8. 1945.

74 Podaci dobiveni iz: HR-DAZG-1184-KSGZ, inventar.

75 Službeni list Demokratske Federalne Jugoslavije, 2 (1945), 17; LAPENNA, Zbornik zakona, uredaba i naredaba, 24-25; SIROTKOVIĆ, ZAVNOH. Zbornik 1945, 650-653; DIZDAR et al., Dokumenti, 94-97.

76 Službeni list Federalne Hrvatske (Beograd), 2 (1945); LAPENNA, Zbornik zakona, uredaba i naredaba, 24-25; SRŠAN, „Sud za zaštitu nacionalne časti”, 263-288; KATZ, „Komunizam i represija”, 145-166; MITROVIĆ, Srpska nacionalna čast, passim; BRUNŠEK, „Procesi pred sodiščem", 106-114. 
podlijegali počinitelji onih djela koja su vrijeđala nacionalnu čast. Konkretnije, radilo se o vršenju akcije i propagande u korist okupatora i njegovih pomagača, širenju nacionalne, vjerske ili rasne nesnošljivosti, opravdavanju okupacije ili osuđivanju narodnooslobodilačke borbe, svakom održavanju prisnih ili prijateljskih odnosa s pripadnicima okupatorske vojske i vlasti, izravnom i neizravnom razgrabljivanju imovine, služenju u činovničkom aparatu, dobrovoljnom privrednom pomaganju okupatoru i njegovim pomagačima te na kraju svakom djelu koje je „išlo za tim da posluži okupatoru i njegovim pomagačima” ${ }^{77}$ Važno je reći da u trenutku njihova počinjenja nisu postojali zakoni kojima su se kažnjavala djela koja su „vrijeđala osjećaj nacionalne časti”, pa je u takvim slučajevima kršeno jedno od osnovnih pravnih načela: nullum crimen sine lege, nulla poena sine lege (ne postoji krivnja ako neko djelo nije zakonom propisano kao kažnjivo). ${ }^{78}$ Prema Uputstvima za rad sudova proizlazi da novi pravni sustav ima cilj štititi novouspostavljene društvene odnose i tek djelomično štititi prava pojedinaca. Pri određenju kaznenoga djela najvažnija je bila njegova društvena opasnost - što bi značilo opasnost za ciljeve NOB-a, pri čemu se nije poštovalo spomenuto načelo nullum crimen sine lege, nego je bila moguća primjena instituta analogije, pa slijedom napomena iz Uputstava proizlazi: „Ako pred narodne sudove dođe koje ovdje nespomenuto djelo, sud će prema njegovoj sličnosti ili srodnosti sa navedenim djelima ustanoviti kamo će to djelo svrstati i prema tome odrediti njegovu prirodu i težinu tj. izreći da li se takovo djelo ima smatrati zločinom, prestupom ili prekršajem i onda će prema tome ustanoviti svoju nadležnost, postupiti i donijeli odluku o krivnji i kazni."79

Sudovi za zaštitu nacionalne časti Hrvata i Srba u Hrvatskoj prestali su s radom 8. rujna 1945., kada je Predsjedništvo Narodnog Sabora donijelo $\mathrm{Za-}$ kon o izmjenama Odluke o zaštiti nacionalne časti Hrvata i Srba u Hrvatskoj, ${ }^{80}$ a njihove zadatke preuzeli su okružni narodni sudovi. ${ }^{81} \mathrm{Za}$ svojega kratkog djelovanja donijeli su oko 3000 presuda koje su se odnosile na industrijalce, poduzetnike, profesore, djelatnike u kulturi i sl. Unatoč velikom broju presuda, član Centralnoga komiteta Komunističke partije Hrvatske Duško Brkić u srpnju 1945., na Prvom savjetovanju načelnika i rukovoditelja OZNA-e za Hrvatsku, izjavio je: „Sudovi za zaštitu nacionalne časti nisu odgovorili svojim zadacima, zato što nisu shvatili naši okružni komiteti i sudovi njihov

77 LAPENNA, Zbornik zakona, uredaba i naredaba, 24-25; SRZENTIĆ, STAJIĆ, Krivično pravo Federativne Narodne Republike Jugoslavije, 62.

78 I u kaznenom zakonodavstvu izbrisano je to načelo jer je predviđena mogućnost izricanja kazni svake vrste za svako kazneno djelo. Takav postupak opravdava i javni tužitelj FNRJ Jože Vilfan, prema kojem je postojeće revolucionarno načelo diktirano „promjenjivošću važnosti krivičnog djela za stabilnost političkog sustava, jer se unaprijed ne može sve odrediti. [...] krivično djelo može danas biti manje važno, ali već preko noći može dobiti prvorazrednu važnost”. RADELIĆ, Hrvatska u Jugoslaviji, 64.

79 SIROTKOVIĆ, ZAVNOH. Zbornik 1944, 458.

80 LAPENNA, Zbornik zakona, uredaba i naredaba, 488.

81 DIZDAR et al., Dokumenti, 263; PERIĆ, Hrvatski državni sabor, sv. 3, 175. 
značaj kao revolucionarnih sudova, nisu shvatili da su to forme za brzo i energično čišćenje neprijatelja iz naših redova. Nama se dao jedan kratki period vremena za trajanje tih revolucionarnih sudova, kao što je Sud nacionalne časti i Vojni sudovi, da bi u najkraće vrijeme očistili zemlju od neprijateljskih elemenata, bilo kaznom smrti ili robijom, kako bi neprijatelja onemogućili i zahvatili stvar u svoje ruke [...] Mi nismo dosta brzo djelovali. Gradjanstvo nije nikada bilo za NOB i mi nismo uspjeli da stvar uhvatimo u svoje ruke. A sud nacionalne časti formiran je unazad nekoliko dana. Trebalo je da se ukaže na hitnost rada revolucionarnih sudova." 82 Svjesnost da su slučajevi koji su se našli pred tim sudovima imali veliko političko značenje potvrđuju i riječi javnoga tužitelja Hrvatske, prema kojima se razmišljalo o donošenju odluke da optužbu pred vojnim sudovima zastupaju isključivo javni tužitelji s obzirom na to „[...] da ogromni dio sudjenja pred Vojnim sudovima ima danas politički karakter". 83

Koliko su suđenja pred vojnim sudovima bila važna za novu vlast možda najbolje oslikavaju općenite brojke sa savezne razine - prema dostupnim podacima proizlazi da su prvostupanjski vojni sudovi u Jugoslaviji od 1945. do 1947. riješili 54473 predmeta, u kojima je sveukupno optuženo 75949 osoba (29 778 vojnih osoba i 46171 nevojna osoba). Od toga ukupnog broja 33884 predmeta riješeno je tijekom 1945. godine. Ovoj brojci treba dodati i mnoge druge riješene predmete (pomilovanja, amnestije, izvršenje kazne), čime se dobiva potpunija slika o radu i djelovanju vojnih sudova u neposrednom poraću. ${ }^{84}$ Usto je važno napomenuti da ne postoje konkretni podaci o vrstama kazni na koje su te osobe osuđene.

Ono što je posebno naglašeno odnosi se na zanimanje javnosti za suđenja, „osobito pred sudom za zaštitu Nacionalne časti, pa kako je dvorana, u kojoj se sudjenje održava, premalena i ne može primiti svu publiku, to se u važnijim predmetima tok glavne rasprave prenosi zvučnicima, koji se instaliraju po raznim djelovima grada, da cjelo gradjanstvo može pratiti tok glavne rasprave" ${ }^{85}$ Ove zadnje rečenice idu u prilog opisu općega stanja, kada se kaže: „Vrlo dobar utisak dalo je sudjenje ratnim špekulantima. Prije samog sudjenja nekolicini ratnih špekulanata sakupilo se veliki broj radnika i tom prilikom demonstrirali protiv istih." ${ }^{86}$ Iz ovih rečenica evidentno je kakve su sve zadatke imala ta poslijeratna suđenja i koliko je propaganda u javnosti bila važna i učinkovita za novu vlast. Stoga se može zaključiti da su sudovi za zaštitu nacionalne časti Hrvata i Srba u Hrvatskoj bili „[...] zapravo revolucionarni sudovi protiv imućnijih građana i privatnog vlasništva, a cilj njihova djelova-

82 DIZDAR et al., Dokumenti, 235; GEIGER et al., Dokumenti: Slavonija, Srijem i Baranja, 343-344; GEIGER et al., Dokumenti: Zagreb i središnja Hrvatska, 577-578.

83 HR-HDA-421-JT SRH, kut. 5, br. 22/45, 9. 6. 1945.

84 KALOĐERA, Vojni pravosudni organi, 34-35; GOJKOVIĆ, Historija jugoslovenskog vojnog pravosuda, 141.

85 GEIGER et al., Dokumenti: Zagreb i središnja Hrvatska, 544-545.

86 DIZDAR et al., Dokumenti, 219; GEIGER et al., Dokumenti: Zagreb i središnja Hrvatska, 548 . 
nja bilo je stvaranje državnog sektora pod izravnim nadzorom vlasti” ${ }^{87}$ Osim imovine, osuđenici su gubili i građanska prava, a time i izborno pravo, čime je osigurano isključivanje bogatoga i poduzetničkoga sloja iz ondašnjega gospodarstva i politike. ${ }^{88}$

Koliko su optužbe/presude redovnih, a posebice presude sudova za zaštitu nacionalne časti bile utemeljene, potvrđuje i činjenica da je veći dio njih oprošten prema Ukazu o općoj amnestiji i pomilovanju od 3. kolovoza 1945. godine. ${ }^{89} \mathrm{U}$ dodatnom objašnjenju stajalo je: „Ukaz pretstavlja dokaz snage i čvrstine naše države, te dokaz potpunog uvjerenja, da neprijatelji slobode naših naroda nisu više u stanju ugroziti tekovine oslobodilačke borbe, pa se može pristupiti opraštanju krivice velikom dijelu onih, koji su pomogli neprijatelja u borbi protiv našeg naroda." 90 Sudovima je posebno naglašeno da će Ukaz postići željeni učinak samo ako ga se hitro provede. U skladu s tim, trebalo je preispitati sve donesene presude po kojima se izdržava kazna (obavijestiti logore) ili one koje su u postupku formulirati prema Ukazu. Nadalje: „Prilikom puštanja, naročito grupnog, uprave logora, odnosno sudovi, sa nekoliko riječi obrazložit će otpuštenim osudjenicima politički značaj Ukaza i širokogrudnost narodnih vlasti, koje vode računa o svim građanima i koje i ovim aktom širokogrudnosti, opraštajući krivice i kazne, žele omogućiti amnestiranima, da u buduće u radu na obnovi zemlje isprave svoje greške i pomognu izgradnju naše države, za koju do sada nisu ništa učinili." ${ }^{91}$ Iz brojnih dokumenata očito je da popisi s imenima amnestiranih osoba nisu dostavljani na vrijeme i u skladu s opetovanim traženjima. Kao primjer bih izdvojila izvješće Kotarskoga narodnog suda za grad Zagreb od 17. kolovoza 1945., prema kojem je broj pomilovanih i amnestiranih osoba na temelju čl. 6. Ukaza o amnestiji i pomilovanju obuhvaćao 28 osoba. ${ }^{92}$ Nekoliko dana poslije (21. kolovoza 1945.) Okružni narodni sud za grad Zagreb dostavio je svoje izvješće s imenima 67 osoba pomilovanih i amnestiranih na temelju čl. 6. Ukaza o amnestiji i pomilovanju. ${ }^{93}$

87 RADELIĆ, Hrvatska u Jugoslaviji, 63.

88 Prema planu Politbiroa Centralnoga komiteta Komunističke partije Slovenije, sudovi za zaštitu nacionalne časti trebali su završiti svoj rad u „određenom roku”, čime je trebalo biti zaplijenjeno i podržavljeno 80-90 \% industrije. RADELIĆ, Hrvatska u Jugoslaviji, 63; VODUŠEK STARIČ, Prevzem oblasti, 188, 190.

89 „Ukaz o općoj amnestiji i pomilovanju”, Borba, 5. 8. 1945., 4. Ukupan broj amnestiranih spominje se u izvještaju koji je Odjel za ratne zarobljenike Ministarstva narodne obrane FNRJ 20. veljače 1946. uputio Dimitriju Georgijeviću, opunomoćeniku OZNA-e, govoreći da je po Ukazu amnestirano 41320 zarobljenika te da je po dodatnim molbama otpušteno njih još 5035. Vidi: DIZDAR et al., Dokumenti, 313-314.

90 HR-DAZG-1216-ONS GZ, kut. 9, Su: 214/1945, br. 4526/1945, 8. 8. 1945.

91 Isto

92 HR-DAZG-1216-ONS GZ, kut. 9, Su: 89/1945, 17. 8. 1945.

93 HR-DAZG-1216-ONS GZ, kut. 9, Su: 89/1945, 21. 8. 1945. 


\section{Uloga javnoga tužiteljstva}

Više puta u radu su spomenuta izvješća javnih tužitelja, a nova vlast već je sredinom 1944. napominjala da je njihova „funkcija neophodna za prve dane nakon preuzimanja vlasti”. Prvi cjeloviti propis o tužiteljstvu bila je spominjana Odluka AVNOJ-a o ustanovljavanju i dužnosti javnoga tužitelja DFJ od 3. veljače 1945. godine. Odluka je propisivala dva principa organizacije i rada javnoga tužiteljstva: princip jedinstvenosti i princip neovisnosti. Princip jedinstvenosti značio je da je javno tužiteljstvo ustrojeno kao jedinstveni organ. Princip neovisnosti određen je čl. 6. Odluke i prema njemu je javno tužiteljstvo funkcionalno neovisan organ, ali isključivo u odnosu na mjesne organe državne vlasti, a republički i savezni organi nisu obuhvaćeni tim principom.

$\mathrm{Na}$ vrhu sustava bio je savezni javni tužitelj, a njega i njegove zamjenike birala je Savezna skupština. Sa savezne razine postavljani su tužitelji republika i pokrajina, koji su organizirali zaduženja unutar svojih teritorijalnih ovlasti. Tijekom 1945. unutar tužiteljstva djelovala su sljedeća odjeljenja: građansko, kazneno, općeorganizacijsko, personalno, odjeljenje općeg nadzora i odjeljenje OZNA-e te administrativni i računovodstveni odsjek.

U lipnju 1945. u Hrvatskoj je bilo organizirano 15 javnih tužiteljstava, a do kraja godine organiziran je i cijeli sustav. Radilo se o instituciji vlasti koja je imala vrlo široke ovlasti i vrlo visok stupanj samostalnosti u svojem radu. Upravo preko osobe javnoga tužitelja najbolje se vidi koliko je politika utjecala na pravni sustav u neposrednom poraću. Na temelju Odluke AVNOJ-a te privremenih Uputstava tužiteljstvo je organizirano kao centralistički organ koji „ne ulazi u strogi sastav nijedne grupe organa vlasti”. ${ }^{94}$ Njihov zadatak bio je nadzirati rad svih državnih organa - osim predstavničkih tijela. Organizacija rada temeljila se i u ovom slučaju na iskustvima sovjetskoga pravnog sustava. ${ }^{95}$ Javni tužitelj imao je pravo na npr. kazneno gonjenje, podizanje tužbe i žalbe te pravo na zakonsku intervenciju tijekom sudskoga i upravnoga postupka. Osim toga na raspolaganju je imao i izvanredna pravna sredstva, pa je mogao podići zahtjev za zaštitu zakonitosti protiv pravomoćnih odluka sudova i upravnih organa, odnosno mogao je i od svih državnih organa, ustanova ili građana tražiti potrebna obavještenja i dobiti na uvid spise. ${ }^{96}$ Pozitivni elementi u radu tužiteljstva odnosili su se u prvom redu na suzbijanje lokalne samovolje u radu (kao primjer naveden je slučaj koji se odnosio na rad $\mathrm{u}$ Istri) ${ }^{97}$ te povećanje jednoobraznosti u primjeni zakona (kao primjer organizacija i održavanje konferencija). Među negativnim elementima svakako valja izdvojiti činjenicu da su u optužnicama najzastupljeniji bili politički delikti.

U prvoj godini djelovanja rad javnoga tužiteljstva bio je gotovo u cijelosti usmjeren na kazneno gonjenje protivnika novoga sustava i konfiskaciju njiho-

94 KISIĆ KOLANOVIĆ, „Pravno utemeljenje državnocentralističkog sistema”, 58.

95 HRNČEVIĆ, Svjedočanstva, 106.

96 KISIĆ KOLANOVIĆ, „Pravno utemeljenje državnocentralističkog sistema”, 59.

97 O detaljima vidi bilj. 55. 
ve imovine (o važnosti konfiskacije bilo je već riječi). Javno tužiteljstvo imalo je bitnu ulogu i u provođenju Zakona o suzbijanju nedopuštene špekulacije $i$ privredne sabotaže, pri čemu je kaznena politika počiniocima tih kaznenih djela pripisivala element visoke društvene opasnosti, stoga je, očekivano, cjelokupna aktivnost pravosuđa na inicijativu javnoga tužiteljstva po tom pitanju popraćena odgovarajućom političkom formulacijom o ugrožavanju privrednih temelja i ekonomskoga razvoja. Istaknuto je i koliku su političku važnost imala suđenja pred vojnim sudovima te sudovima za zaštitu nacionalne časti Hrvata i Srba u Hrvatskoj - pa je jasna inicijativa prema kojoj bi optužbu u tim slučajevima zastupali isključivo javni tužitelji. No radi cjelovitijega sagledavanja ovoga pitanja valja navesti: „Odgovorni pravnici u tužilaštvu, ma koliko bili svjesni da se ta akcija zasniva na političkoj inicijativi, nastojali su joj dati pravnu formu koja će poštovati minimum zakonitosti." ${ }^{98}$ I uz takva nastojanja, može se zaključiti da su ondašnji sudovi u svojem radu bili u neravnopravnom i podcijenjenom odnosu spram javnoga tužiteljstva.

\section{Izvršavanje presuda}

Prema tumačenju M. Šnuderla, sudstvo nije moguće organizirati ako ne postoje jamstva za prisilu u pitanju izvršenja kazne, pa zaključuje da „ako postoji to jamstvo, [sudstvo] uživa priznanje i poslušnost". ${ }^{99}$ Što se tiče izvršavanja kazni, za njih je do 1. rujna 1945. bilo nadležno republičko Ministarstvo pravosuđa, a nakon toga upute je izdavalo Ministarstvo unutarnjih poslova. ${ }^{100}$ Prema tim uputama, za izvršenje presuda lišavanja slobode i lišavanja slobode s prisilnim radom nadležni su bili okružni (kotarski) sudovi. Kazne u trajanju do tri mjeseca trebale su se izdržavati u zatvorima pri kotarskim i okružnim narodnim sudovima koji su kaznu izrekli. Prema riječima javnoga tužitelja, 1945. u Hrvatskoj se „svakoga i za svako djelo stavljalo u pritvor”. Primjerice, u okružnim sudovima Zagreba, Osijeka, Bjelovara i Slavonskog Broda bilo je pritvoreno 1650 osoba optuženih za kazneno djelo protiv države. ${ }^{101}$

Jedini potpuniji brojčani podaci koji su dostupni odnose se na broj osoba pritvorenih u zatvoru Okružnoga suda za grad Zagreb. Ministarstvo je te podatke tražilo nalogom od 10. listopada 1945., a prvi dostavljeni podaci odnose se na razdoblje od 10. do 20. listopada. Prema njima se u nadležnosti Okružnoga suda za grad Zagreb, Kotarskoga suda za grad Zagreb, Javnoga tužiteljstva za grad Zagreb i Javnoga tužiteljstva za okrug Zagreb našlo 297 osoba. Prema kategorijama, bilo je 9 pritvorenika, 269 osoba nad kojima se provodio istražni postupak i 19 kažnjenika. ${ }^{102}$ Sljedeći dokumenti odnose se na razdoblje od 20. do 31. listopada, a prema njima su se u nadležnosti Okruž-

\footnotetext{
98 KISIĆ KOLANOVIĆ, „Pravno utemeljenje državnocentralističkog sistema”, 60-61.

99 ŠNUDERL, Dokumenti o razvoju ljudske oblasti v Sloveniji, 222.

100 HR-DAZG-1216-ONS GZ, kut. 9, Su: 277/1945, 5. 9. 1945.

101 KISIĆ KOLANOVIĆ, „Pravno utemeljenje državnocentralističkog sistema”, 70.

102 HR-DAZG-1216-ONS GZ, kut. 10, Su: 376/1945, 24. 10. 1945.
} 
noga suda za grad Zagreb, Kotarskoga suda za grad Zagreb, Javnoga tužiteljstva za grad Zagreb i Javnoga tužiteljstva za okrug Zagreb našle ukupno 363 osobe - 16 pritvorenika, 285 u istražnom postupku i 62 kažnjenika. ${ }^{103}$ Podaci koji su poslani za idućih deset dana pokazuju da se u tom razdoblju u nadležnosti Okružnoga suda za grad Zagreb, Kotarskoga suda za grad Zagreb, Javnoga tužiteljstva za grad Zagreb i Javnoga tužiteljstva za okrug Zagreb našlo ukupno 379 osoba, od toga 21 pritvorenik, 294 u istražnom postupku i 64 kažnjenika. ${ }^{104}$ Ukupan broj osoba koje su se u tih mjesec dana našle u zatvoru Okružnoga narodnog suda u Zagrebu je 1039 - od toga 46 pritvorenika, 848 u istražnom postupku i 145 kažnjenika. Ukupne brojke prikazuju tek jedan mjesec, no ne radi se o danima neposredno nakon preuzimanja vlasti, nego o vremenu kada je sustav manje-više funkcionirao, pa su time i brojke realniji pokazatelj. Osim toga, one su i poprilično visoke te podosta svjedoče o radu sudova u Zagrebu i njegovoj okolici.

Broj osoba u zatvoru Okružnoga narodnog suda u Zagrebu

$\begin{array}{lllllll}0 & 200 & 400 & 600 & 800 & 1000 & 1200\end{array}$

10. do 19. listopada

20. do 31. listopada

1. do 10. studenoga

ukupno

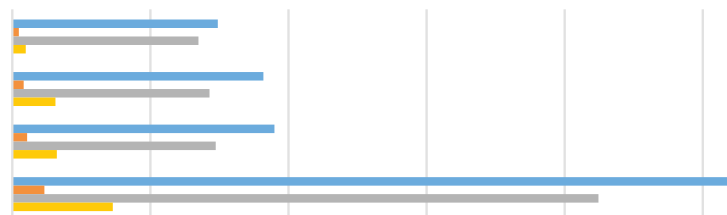

ukupan broj $\quad$ pritvorenici $\quad$ istražni postupak $\quad$ kažnjenici

Za kazne zatvora duže od tri mjeseca bili su organizirani kažnjenički logori. Osuđenike iz Dalmacije, Primorja, Gorskoga kotara ili Istre upućivalo se u logor Vrana kod Biograda na Moru, osuđenike s područja Oblasnoga NOO-a Osijek u logor Bohn (nekadašnja ciglana) kraj Vinkovaca, a osuđenike s ostalih područja u logor Stara Gradiška. ${ }^{105}$ Za područje Like već je postojao kažnjenički logor u Gospiću, pa se očekivalo da kotarski i okružni sudovi Like i nadalje upućuju svoje kažnjenike u taj logor. ${ }^{106}$ Prema dostupnim dokumentima, kazne su izvršavane i u logoru u Buzetu (kraj Gline). ${ }^{107} \mathrm{O}$ nekim

103 HR-DAZG-1216-ONS GZ, kut. 10, Su: 376/1945, 5. 11. 1945.

104 HR-DAZG-1216-ONS GZ, kut. 10, Su: 376/1945, 14. 11. 1945.

105 HR-DAGS-43-SZNČ OL-G, kut. 1, 39/45, 8. 8. 1945.; HR-DAZG-1216-ONS GZ, kut. 9, Su: 215/1945, br. 4484/1945, 8. 8. 1945.; GEIGER et al., Dokumenti: Slavonija, Srijem i Baranja, 159; LAPENNA, Zbornik zakona, uredaba i naredaba, 83-85; SRŠAN, „Sud za zaštitu nacionalne časti”, 264.

106 HR-DAZG-1216-ONS GZ, kut. 9, Su: 215/1945, br. 4484/1945, 8. 8. 1945.

107 DIZDAR et al., Dokumenti, 215-216; GEIGER et al., Dokumenti: Zagreb i središnja Hrvatska, 545 . 
konkretnijim brojčanim podacima, tj. o osobama koje su osuđene na izdržavanje kazne u tim logorima danas nije moguće pouzdano govoriti. No kao primjer bih izdvojila slučaj žene koja je preko dva mjeseca boravila u logoru Vrana. U statističkom listu o njezinu boravku stoji da nije imala nikakvih interesa ni za politiku ni za kulturu ni za zabavu. Ali najznakovitije pitanje odnosilo se na kategoriju „Opća ocjena njegovog karaktera, kako je kazna na njega utjecala, da li se popravio i da li je sposoban za neki naročiti posao”. Po tom pitanju optuženica nije dobila prolaznu ocjenu, a njezin je „odnos prema NOPu slab, vređa Narodnu Vlast, Karaktera slaboga, drska, kazna na nju je donekle i uticala, sposobna za domaćinstva" ${ }^{108}$ Ukratko, preodgoj na nju ipak nije djelovao.

\section{Zaključak}

Ako pokušam sve sažeti i s nekoliko riječi zaključiti o bitnim karakteristikama poslijeratnoga zakonodavstva i sudstva, mislim da neću pogriješiti poslužim li se riječima Ferde Čulinovića i Leona Gerškovića, koji su u izlaganju iznijeli: „Ovo zakonodavstvo nosi na sebi jasni žig svoga vremena. Na njemu se vidi, da je ono rođeno u borbi, da je upravljeno na čuvanje tekovina naše borbe i da mu je osnovni cilj opća dobrobit naroda, združenog i sjedinjenog u bratskom pregnuću da zemlju oslobodimo od okupatora i onih koji mu služe."109 Takvo revolucionarno pravo, po uzoru na gotovo istovjetne izvedenice iz sovjetskoga prava, smatralo je ništavnim svaki pravni čin koji je bio suprotan zajedničkim interesima. Nadalje, pravne norme trebale su proizlaziti iz potreba socijalnoga života, tj. iz pučkoga prava, u prvom redu oslanjajući se na postojeće običaje. Konkretnije, pojedini zakoni donošeni su u skladu s političkim trenutkom i potrebama. Opravdano se, s obzirom na vrijeme i uvjete, postavlja pitanje donošenja privremenih pravnih normi, no ondašnji pravnici nisu bili skloni takvim rješenjima s obzirom na to da je to u suprotnosti s principom o stalnosti zakona te činjenicom po kojoj bi zakoni trebali utvrđivati postojeće stanje. Smatrali su da se pomanjkanje pravnih normi može na zadovoljavajući način nadomjestiti održavanjem redovitih sastanaka/konferencija na kojima su suci upućivali ostale u postojeću pravnu praksu. ${ }^{110}$ Princip zakonitosti „nije formalistički princip pridržavanja slova zakona. Raditi zakonito znači za nas ostvarivati principe NOB-e izražene u zakonima. Zakon nije za nas okvir i šema, zakon je uput za djelatnost sa određenim ciljem. Pozivati se na slovo zakona protiv njegova duha ne bi bilo za nas zakonito. Znati pravilno ostvarivati naše zakone, to znači saživiti se sa principima borbe, znači razlikovati duh od slova zakona, znači boriti se jed-

${ }^{108}$ HR-DAGS-43-SZNČ OL-G, kut. 1, 3/45; MATKOVIĆ, TOPIĆ, Zločini Jugoslavenske armije, 591.

109 ČULINOVIĆ, GERŠKOVIĆ, „Smjernice našeg zakonodavstva”, 179.

110 VODUŠEK STARIČ, Kako su komunisti osvojili vlast, 56. 
nako protiv bezakonja i nereda kao i formalističkog shvaćanja zakona". ${ }^{111}$ Je li nepostojanje točno definiranih pravnih normi bilo otegotna okolnost za novu vlast? Čini se da nije. Zakonodavna nedosljednost bila je čak i prednost koju je Komunistička partija uvelike koristila vidjevši u tome prostor za izravne političke direktive.

Što se tiče organizacije sudova u neposrednom poraću, jasno je da je ona bila temeljena na centralizaciji i jedinstvu vlasti. Koliko je jednakost u uređenju narodnih sudova uistinu zaživjela - i danas je otvoreno pitanje. Pred poslijeratno sudstvo, i redovno i ono koje je djelovalo po „posebnim uvjetima”, očekivano su postavljeni veliki zadaci. Prema riječima Jakova Blaževića na Prvom kongresu pravnika antifašista Hrvatske, održanom u Glini (12. - 14. kolovoza 1944.): „Narodi Jugoslavije borbom su pretvorili čitavu Jugoslaviju u sudnicu, gdje se kroji istinska pravda, izvršuju pravedne i nemilosrdne kazne nad okupatorom i neprijateljima vlastitog naroda." U daljnjim objašnjenjima rečeno je koji je osnovni princip: „[...] da se narodno sudovanje i uprava ne smiju udaljavati od naroda. Ne smiju zato što je samo ono sudstvo narodno i ona uprava narodna koja u narodnim masama ima svoj izvor i najviši autoritet." ${ }^{112}$ Organizacija sudova na području Hrvatske odvijala se različitim intenzitetom. Na nju su utjecali i mnogi objektivni razlozi - završetak ratnih operacija, povezanost i komunikacija sa središnjim institucijama te brojni drugi elementi. Dodatni problem bio je i manjak stručnoga kadra u radu sudova. Iako se to u javnosti nastojalo tumačiti time da su suci prije svega „narodni ljudi”, ta se nestručnost očitovala i u brojnim neutemeljenim i/ili nedovoljno pripremljenim optužnicama/presudama. Upozorenja na tu činjenicu dolazila su i od Vrhovnoga suda i od Ministarstva pravosuđa Narodne Republike Hrvatske, i to krajem godine, a ne samo u danima neposredno nakon završetka ratnih operacija. Iz prezentiranih dokumenata jasno se vidi i pozicija tužiteljstva, tj. javnoga tužitelja u neposrednom poraću, njegova politička važnost i mogućnosti - koje su bile gotovo pa neograničene.

Važan element bio je i rad Suda za zaštitu nacionalne časti Hrvata i Srba u Hrvatskoj, koji je u svojem kratkom djelovanju donio niz presuda kojima su iz društvenoga života isključeni ugledni pojedinci, ali i svi oni koji su na bilo koji način mogli biti opasnost za novi poredak. Pritom nikako ne treba ispustiti iz vida važno pitanje konfiskacije privatne imovine, kojom je stečena gotovo cjelokupna poslijeratna državna imovina. Na kraju, o utemeljenosti presuda redovnih i „specijalnih” sudova govori i činjenica da je veći dio njih oprošten prema Ukazu o općoj amnestiji i pomilovanju od 3. kolovoza 1945. godine. Stoga je u državnopravnoj izgradnji nakon rata teško razlučiti granicu između političke sfere i formalnoga prava.

111 GERŠKOVIĆ, „Problemi izgradnje naše državne uprave”, 109.

112 BLAŽEVIĆ, „Zadaci pravnika u narodnooslobodilačkom pokretu”, 68-69. 


\section{Arhivski izvori}

HR-DAGS-43-SZNČ OL-G: Hrvatska, Državni arhiv u Gospiću, Gospić, fond 43, Sud za zaštitu nacionalne časti za okrug Liku - Gospić.

HR-DAZG-1184-KSGZ: Hrvatska, Državni arhiv u Zagrebu, Zagreb, fond 1184, Kotarski sud za grad Zagreb (1945. - 1995.).

HR-DAZG-1216-ONS GZ: Hrvatska, Državni arhiv u Zagrebu, Zagreb, fond 1216, Okružni narodni sud za grad Zagreb (1945. - 1949.).

HR-HDA-421-JT SRH: Hrvatska, Hrvatski državni arhiv, Zagreb, fond 421, Javno tužilaštvo Socijalističke Republike Hrvatske.

SR-AJ-15-PNS FNRJ: Srbija, Arhiv Jugoslavije, Beograd, fond 15, Prezidijum Narodne skupštine Federativne Narodne Republike Jugoslavije.

SR-AJ-49-MPV FNRJ: Srbija, Arhiv Jugoslavije, Beograd, fond 49, Ministarstvo pravosuđa Vlade Federativne Narodne Republike Jugoslavije.

\section{Objavljeni izvori i tisak}

Borba (Beograd), 1945.

DIZDAR, Zdravko; GEIGER, Vladimir; POJIĆ, Milan; RUPIĆ, Mate, prir. Partizanska i komunistička represija i zločini u Hrvatskoj 1944. - 1946. Dokumenti. Slavonski Brod: Hrvatski institut za povijest, Podružnica za povijest Slavonije, Srijema i Baranje, 2005.

DŽELEBDŽIĆ, Milovan. Zbornik dokumenata i podataka o narodnooslobodilačkom ratu naroda Jugoslavije, tom II, knj. 13: Dokumenta Centralnog komiteta KP Jugoslavije i Vrhovnog štaba NOV i PO Jugoslavije. Beograd: Vojnoistorijski institut, 1982.

GEIGER, Vladimir; RUPIĆ, Mate; DIZDAR, Zdravko; PENAVA, Šimun, prir. Partizanska i komunistička represija i zločini u Hrvatskoj 1944. - 1946. Dokumenti, sv. 2: Slavonija, Srijem i Baranja. Slavonski Brod: Hrvatski institut za povijest, Podružnica za povijest Slavonije, Srijema i Baranje, 2006.

GEIGER, Vladimir; RUPIĆ, Mate; KEVO, Mario; KRALJEVIĆ, Egon; DESPOT, Zvonimir, prir. Partizanska i komunistička represija i zločini u Hrvatskoj 1944. - 1946. Dokumenti, sv. 3: Zagreb i središnja Hrvatska. Slavonski Brod; Zagreb: Hrvatski institut za povijest, Podružnica za povijest Slavonije, Srijema i Baranje; Hrvatski institut za povijest, 2008.

Narodne novine (Zagreb), 107 (1946).

Primorski vjesnik (Rijeka), 1945.

SIROTKOVIĆ, Hodimir, ur. Zemaljsko antifašističko vijeće narodnog oslobođenja Hrvatske. Zbornik dokumenata 1944 (Od 10. svibnja do 31. prosinca). Zagreb: Institut za historiju radničkog pokreta Hrvatske, 1975.

SIROTKOVIĆ, Hodimir, ur. Zemaljsko antifašističko vijeće narodnog oslobođenja Hrvatske. Zbornik dokumenata 1945 (Od 1. siječnja do 25. srpnja). Zagreb: Institut za historiju radničkog pokreta Hrvatske, 1985. 
Službeni list Demokratske Federativne Jugoslavije (Beograd), 2, 4, 36, 40, 65, 66, 67 (1945).

Službeni list Federalne Hrvatske (Beograd), 2 (1945).

Službeni list Federativne Narodne Republike Jugoslavije (Beograd), 59 (1946).

Vjesnik (Zagreb), 1945.

Zbirka krivičnih zakona sa komentarom. Beograd, 1947.

\section{Literatura}

ANIĆ, Tomislav. „Normativni okviri podržavljenja imovine u Hrvatskoj/Jugoslaviji 1944. - 1946.” Časopis za suvremenu povijest 39 (2007), br. 1: 25-62.

BASTAIĆ, Konstantin. „Razvitak organa pravosuđa u novoj Jugoslaviji”. U: Nova Jugoslavija. Pregled državnopravnog razvitka povodom desetogodišnjice Drugog zasjedanja AVNOJ-a, ur. Ferdo Čulinović. Zagreb: Institut za historiju države i prava Pravnog fakulteta, 1954, 67-116.

BAVCON, Ljubo. Kazneno-pravna zaštita države i njenog društvenog uređenja. Zagreb: Globus, 1988.

BLAŽEVIĆ, Jakov. „Zadaci pravnika u narodnooslobodilačkom pokretu". U: Spomenica Prvog kongresa pravnika antifašista Hrvatske, Glina 12. 14. kolovoza 1944., ur. Hodimir Sirotković. Zagreb: Savez društva pravnika Hrvatske, 1974, 67-71.

BRUNŠEK, Roman. „Procesi pred sodiščem slovenske narodne časti v Ljubljani”. Kronika 43 (1995), br. 1-2: 106-114.

CVETKOVIĆ, Srđan. Između srpa i čekića. Represija u Srbiji 1944-1953. Beograd: Institut za savremenu istoriju, 2006.

ČULINOVIĆ, Ferdo; GERŠKOVIĆ, Leo. „Smjernice našeg zakonodavstva”. U: Spomenica Prvog kongresa pravnika antifašista Hrvatske, Glina 12. - 14. kolovoza 1944., ur. Hodimir Sirotković. Zagreb: Savez društva pravnika Hrvatske, 1974, 178-181.

FERENC, Mitja. Kočevska pusta in prazna. Nemško jezikovno območje na Kočevskem po odselitvi Nemcev. Ljubljana: Modrijan, 2005.

GERŠKOVIĆ, Leon. Dokumenti o razvoju narodne vlasti. Beograd: Odbor za objavljivanje predavanja na pravnom fakultetu, 1946.

GERŠKOVIĆ, Leo. „Problemi izgradnje naše državne uprave”. U: Spomenica Prvog kongresa pravnika antifašista Hrvatske, Glina 12. - 14. kolovoza 1944., ur. Hodimir Sirotković. Zagreb: Savez društva pravnika Hrvatske, 1974, 105-110.

GOJKOVIĆ, Miloš. Historija jugoslovenskog vojnog pravosuđa. Beograd: Vojska, 1999.

HRNČEVIĆ, Josip. Svjedočanstva. Zagreb: Globus, 1984. 
JURČEVIĆ, Josip; IVANDA, Katica. „Ustrojavanje sustava jugoslavenskih komunističkih vojnih sudova tijekom Drugog svjetskog rata i poraća”. Društvena istraživanja 15 (2006), br. 4-5: 891-915.

KALOĐERA, Marko. Vojni pravosudni organi i pravne službe JNA. Beograd: Vojnoizdavački i novinski centar, 1986.

KATZ, Vera. „Komunizam i represija: Sud narodne časti u Bosni i Hercegovini”. U: 60 godina od završetka Drugog svjetskog rata - kako se sjećati 1945. godine, ur. Husnija Kamberović. Sarajevo: Institut za istoriju u Sarajevu, 2006, 145-166.

KISIĆ KOLANOVIĆ, Nada. „Neki aspekti razvoja prava na oslobođenom teritoriju Hrvatske 1943-1945. godine. U povodu 45. godišnjice ZAVNOH-a”. Časopis za suvremenu povijest 19 (1987), br. 3: 1-24.

KISIĆ KOLANOVIĆ, Nada. „Pravno utemeljenje državnocentralističkog sistema u Hrvatskoj 1945. - 1952. godine”. Časopis za suvremenu povijest 24 (1992), br. 1: 49-99.

KISIĆ KOLANOVIĆ, Nada. „Razvoj narodne vlasti u Hrvatskoj 1943 1945.” Magistarski rad, Sveučilište u Zagrebu, 1979.

LAPENNA, Ivo. Zbornik zakona, uredaba i naredaba. Zagreb: Narodne novine, Službeni list Federalne Hrvatske, 1945.

LEGRADIĆ, Rudolf; BESAROVIĆ, Mirko. Narodni sudovi i javno tužioštvo u novoj Jugoslaviji. Beograd: Udruženje pravnika FNRJ, 1948.

MATKOVIĆ, Blanka; TOPIĆ, Ranko. Zločini Jugoslavenske armije i komunistička represija na području Like i grada Gospića 1945. godine: Dokumenti, svjedočanstva i grobišta (1944. - 1998.). Zagreb: Hrvatska družba povjesničara „Dr. Rudolf Horvat”, 2019.

MEANDŽIJA, Petar. „Iskustva iz našeg narodnog sudstva”. U: Spomenica Prvog kongresa pravnika antifašista Hrvatske, Glina 12. - 14. kolovoza 1944., ur. Hodimir Sirotković. Zagreb: Savez društva pravnika Hrvatske, 1974, 111 115.

MIKOLA, Milko. „Povojne nasilne razlastitve premoženja v Sloveniji”. U: Temna stran meseca. Kratka zgodovina totalitarizma v Sloveniji 1945 - 1990, ur. Drago Jančar. Ljubljana: Nova revija, 1998, 53-64.

MIKOLA, Milko. Zaplembe premoženja v Sloveniji 1943 - 1952. Celje: Zgodovinski arhiv, 1999.

MILIĆEVIĆ, Nataša. Jugoslovenska vlast i srpsko građanstvo 1944 - 1950. Beograd: Institut za noviju istoriju Srbije, 2009.

MITROVIĆ, Momčilo. Srbija 1944 - 1952. Beograd: Centar za kulturu Požarevac - edicija Braničevo; Institut za istoriju radničkog pokreta, 1988.

MITROVIĆ, Momčilo. Srpska nacionalna čast pred zakonom 1945. godine. Beograd: Institut za noviju istoriju Srbije, 2007.

NEŠOVIĆ, Slobodan. Zakonodavni rad Pretsedništva Antifašističkog veća narodnog oslobođenja Jugoslavije i Pretsedništva Privremene narodne skupšti- 
ne (19 novembra 1944 - 27 oktobra 1945) po stenografskim beleškama i drugim izvorima. Beograd: Prezidijum Narodne skupštine FNRJ, 1951.

NOVAK, Božidar; STOPAR, Vladimir. Vjesnik jedinstvene narodno-oslobodilačke fronte Hrvatske 1941. - 1945. (izbor - tom I). Zagreb: Vjesnik, 1970.

PERIĆ, Ivo. Hrvatski državni sabor 1848. - 2000., sv. 3: 1918. - 2000. Zagreb: Hrvatski institut za povijest; Dom i svijet, 2000.

PORTMANN, Michael. „Communist retaliation and persecution on Yugoslav territory during and after WWII (1943 - 1950)". Tokovi istorije (2004), br. 1-2: 45-74.

RADELIĆ, Zdenko. Hrvatska u Jugoslaviji 1945. - 1991. Od zajedništva do razlaza. Zagreb: Školska knjiga; Hrvatski institut za povijest, 2006.

SRŠAN, Stjepan. „Sud za zaštitu nacionalne časti Hrvata i Srba u Hrvatskoj za okrug Osijek - Virovitica 1945. godine”. Glasnik arhiva Slavonije i Baranje 8 (2005): 263-288.

SRZENTIĆ, Nikola; STAJIĆ, Aleksandar. Krivično pravo Federativne Narodne Republike Jugoslavije. Opšti deo. Beograd: Savez udruženja pravnika Jugoslavije, 1954.

ŠNUDERL, Makso. Dokumenti o razvoju ljudske oblasti v Sloveniji. Ljubljana: Uradni list Republike Slovenije, 1949.

ŠNUDERL, Makso. Materialno kazensko pravo $v$ Narodnoosvobodilni vojni Slovenije. Ljubljana: Novi svet, 1947.

VODUŠEK STARIČ, Jera. Kako su komunisti osvojili vlast 1944. - 1946. Zagreb: Naklada Pavičić, 2006.

VODUŠEK STARIČ, Jera. „Ozadje sodnih procesov v Sloveniji v prvem povojnem letu”. Prispevski za novejšo zgodovino 32 (1992), br. 1-2: 139-154.

VODUŠEK STARIČ, Jera. Prevzem oblasti 1944 - 1946. Ljubljana: Cankarjeva založba, 1992. 


\section{The Development of Judicial Authorities and the Related Legal Framework in Croatia in 1945}

The organisation of the new government in the immediate aftermath of the war in Croatia encompassed and largely relied on the formation and development of judicial institutions and the accompanying legal regulations. This paper analyses the circumstances and conditions in which the judicial system was established and the tasks set before the post-war judiciary. It was essential to review how the regulations were standardised and how regular (circuit and district) courts and short-lived 'special' courts, whose consequences were far-reaching, operated. It is important to highlight the significance of public prosecutors in Croatia. Through analysing archival sources and the available literature, an attempt was made to determine the extent that the legal vacuum that appeared after the severance of all ties with the pre-war laws made it easier to implement the new system, which sought to secure not only its own legality, but also the legitimacy of its authority.

Key words: judiciary; courts; laws; public prosecutor; Yugoslavia; Croatia; 1945. 